\title{
Communication
}

\section{Genetic Polymorphisms of 5-HT Receptors and Antipsychotic-Induced Metabolic Dysfunction in Patients with Schizophrenia}

\author{
Diana Z. Paderina ${ }^{1}\left(\mathbb{D}\right.$, Anastasiia S. Boiko ${ }^{1}{ }^{\oplus}$, Ivan V. Pozhidaev ${ }^{1}\left(\mathbb{D}\right.$, Anna V. Bocharova ${ }^{2}\left(\mathbb{D}\right.$, Irina A. Mednova ${ }^{1}(\mathbb{D}$, \\ Olga Yu. Fedorenko ${ }^{1}$, Elena G. Kornetova ${ }^{1,3}{ }^{\oplus}$, Anton J.M. Loonen ${ }^{4, *} \mathbb{C}$, Arkadiy V. Semke ${ }^{1 \mathbb{C}}$, \\ Nikolay A. Bokhan ${ }^{1,3}$ and Svetlana A. Ivanova ${ }^{1,3}$ (i)
}

Citation: Paderina, D.Z.; Boiko, A.S.; Pozhidaev, I.V.; Bocharova, A.V.; Mednova, I.A.; Fedorenko, O.Y.; Kornetova, E.G.; Loonen, A.J.M.; Semke, A.V.; Bokhan, N.A.; et al. Genetic Polymorphisms of 5-HT Receptors and Antipsychotic-Induced Metabolic Dysfunction in Patients with Schizophrenia. J. Pers. Med. 2021, 11, 181. https://doi.org/10.3390/ jpm11030181

Academic Editor: Tomiki Sumiyoshi

Received: 4 February 2021

Accepted: 2 March 2021

Published: 5 March 2021

Publisher's Note: MDPI stays neutral with regard to jurisdictional claims in published maps and institutional affiliations.

Copyright: (c) 2021 by the authors. Licensee MDPI, Basel, Switzerland. This article is an open access article distributed under the terms and conditions of the Creative Commons Attribution (CC BY) license (https:/ / creativecommons.org/licenses/by/ $4.0 /)$.
1 Mental Health Research Institute, Tomsk National Research Medical Center of the Russian Academy of Sciences, 634014 Tomsk, Russia; osmanovadiana@mail.ru (D.Z.P.); anastasya-iv@yandex.ru (A.S.B.); craig1408@yandex.ru (I.V.P.); irinka145@yandex.ru (I.A.M.); f_o_y@mail.ru (O.Y.F.); kornetova@sibmail.com (E.G.K.); asemke@tnimc.ru (A.V.S.); bna909@gmail.com (N.A.B.); ivanovaniipz@gmail.com (S.A.I.)

2 Research Institute of Medical Genetics, Tomsk National Research Medical Center of the Russian Academy of Sciences, 634050 Tomsk, Russia; anna.bocharova@medgenetics.ru

3 Siberian State Medical University, 634050 Tomsk, Russia

4 Unit of PharmacoTherapy, -Epidemiology \& -Economics, Groningen Research Institute of Pharmacy, University of Groningen, 9713AV Groningen, The Netherlands

* Correspondence: a.j.m.loonen@rug.nl

\begin{abstract}
Background: Antipsychotic-induced metabolic syndrome (MetS) is a multifactorial disease with a genetic predisposition. Serotonin and its receptors are involved in antipsychotic-drug-induced metabolic disorders. The present study investigated the association of nine polymorphisms in the four 5-hydroxytryptamine receptor (HTR) genes HTR1A, HTR2A, HTR3A, and HTR2C and the gene encoding for the serotonin transporter SLC6A4 with MetS in patients with schizophrenia. Methods: A set of nine single-nucleotide polymorphisms of genes of the serotonergic system was investigated in a population of 475 patients from several Siberian regions (Russia) with a clinical diagnosis of schizophrenia. Genotyping was performed and the results were analyzed using chi-square tests. Results: Polymorphic variant rs521018 (HTR2C) was associated with higher body mass index in patients receiving long-term antipsychotic therapy, but not with drug-induced metabolic syndrome. Rs1150226 (HTR3A) was also associated but did not meet Hardy-Weinberg equilibrium. Conclusions: Our results indicate that allelic variants of HTR2C genes may have consequences on metabolic parameters. MetS may have too complex a mechanistic background to be studied without dissecting the syndrome into its individual (causal) components.
\end{abstract}

Keywords: schizophrenia; antipsychotics; body mass index; weight gain; metabolic syndrome; serotonin; genes; pharmacogenetics

\section{Introduction}

Antipsychotics are important therapeutic agents for patients with schizophrenia, but long-term use of these drugs increases the risk of developing type 2 diabetes mellitus, hyperlipidemia, and hypertension [1-6]. These drugs are known to increase the prevalence of metabolic syndrome (MetS), which is a clustering of well-known cardiovascular risk factors and is known to be augmented in a variety of psychiatric disorders [6]. Apart from increasing the likelihood of serious cardiovascular and malignant pathologies, significant weight gain can also affect compliance and cause a decrease in the quality of life of patients with schizophrenia, since, in addition to the stigma of schizophrenia, there is the stigma of obesity [7]. 
Several G protein-coupled receptors, mainly dopamine, serotonin, and noradrenaline receptors, are traditional molecular targets for antipsychotics [8]. The efficacy of classical antipsychotics was mainly associated with the antagonism of dopamine type 2 (D2) receptors. Atypical antipsychotics are far more complex D2 receptor antagonists and act beyond $\mathrm{D} 2$ antagonism, involving other receptor targets that regulate dopamine and other neurotransmitters. Therefore, atypical antipsychotics have fewer adverse effects like parkinsonism, hyperprolactinemia, apathy, etc., which are all linked to the strong blockade of D2 receptors [9]. A variety of mechanisms contribute to how treatment with antipsychotic drugs results in metabolic syndrome $[3,10,11]$. Roughly three components can be distinguished, related to behavioral (reward-seeking, neuropsychoimmunological), hypothalamic endocrine (appetite/satiety), and peripheral (adipocytes, immune system, abdominal organs) regulation [10]. Serotonergic (serotonin, 5-Hydroxytryptamine, 5-HT) neurotransmission appears to be involved in all three of them as well as in the pathophysiology of schizophrenia [12]. Circuits regulating the intensity of reward-seeking and distress-avoiding behaviors are controlled by the habenuloid complex via ascending monoaminergic terminals originating in the upper brainstem [13-15]. Mesencephalic $5-H T$ neurons projecting to the striatum, prefrontal cortex, and amygdaloid complex increase the intensity of distress-avoiding behavior directly and also indirectly by inhibiting dopaminergic and adrenergic neurons [16-18]. Serotonergic neurotransmission also has a key role concerning obesity through both cerebral and peripheral mechanisms $[11,19,20]$. Moreover, most atypical antipsychotic drugs have a considerable affinity to certain 5-HT receptors $[18,21,22]$.

Seven types of 5-HT receptors have been identified, all but one (5-HT3) being G-protein coupled receptors (GPCRs) [18,23]. When also considering subtypes, at least 13 of these GPCRs can be distinguished [23]. 5-HT1A is a post-synaptic receptor in limbic forebrain structures and a somatodendritic autoreceptor of 5-HT neurons of the raphe nuclei. 5-HT1A is also expressed by cholinergic neurons within both the brain and the gastrointestinal system. 5-HT1A inhibits neuronal firing and neurotransmitter release via Gi/o-proteincoupled $\mathrm{K}^{+}$channels (GIRK channels) [23]. Receptors of type 5-HT2 are widely distributed within the brain [24] but also have an important role in vascular contractility (5-HT2A, 5-HT2B), colonic motor function (5-HT2B), and voiding (5-HT2C) [18,23,25-27]. 5-HT2 subtypes are coupled to $\mathrm{Gq} / 11$, which increases inositol 1,4,5-triphosphate levels and facilitates neuronal depolarization but, due to the activation of GABAergic interneurons, frequently inhibit their targets [18]. A characteristic of 5-HT2C (and, to a lesser extent, 5-HT2A) is constitutive activity, which enables clozapine to have inverse agonistic effects [28]. 5-HT3 subtypes are expressed by central and peripheral neurons where they induce rapid depolarization/repolarization by the opening of non-selective cation channels [23]. 5-HT3 within the lower brainstem is involved in vomiting and consists of 5- HT3A subunits, while 5-HT3 subtypes on the peripheral (autonomic and somatosensory) neurons have profound effects on the cardiovascular system and regulate motility and secretion throughout the whole gastrointestinal system [23]. This peripheral 5-HT3 consists of a heteromeric combination of 5-HT3A and 5-HT3B subunits.

Several $H T R$ genes are involved in the regulation of metabolic homeostasis, including HTR1B, HTR1F, HTR2A/2C, HTR3, and HTR6 [11,19,20]. As MetS has a significant genetic component $[29,30]$, genes encoding for these 5-HT receptors can be considered good candidates for genetic association studies particularly aimed at studying the molecular mechanism responsible for drug-induced weight gain. Most often studied are singlenucleotide polymorphisms (SNPs) of the HTR2A and HTR2C genes, since the effect of atypical antipsychotics on hypothalamic $5-H T 2 A / 2 C$, in particular, is believed to contribute to drug-induced weight gain $[7,10,11,31]$. Moreover, polymorphic variants of the HTR2A gene are associated with higher body mass index (BMI) [32], greater waist circumference, and other components of metabolic syndrome [33]. Single-nucleotide polymorphisms of the HTR2C gene are also associated with obesity, weight gain, and BMI [34-38]. In a study by Yuan et al. [38], several haplotypes of the promoter region of HTR2C were identified 
and associated with obesity and diabetes. A pharmacogenetic study of other genes of the serotonergic system (HTR3A, HTR3B) did not reveal associations with weight gain induced by antipsychotics [39].

Studying the association of functional genetic variants with specific clinical phenomena can be applied to elucidate their mechanistic background [40]. We applied this investigational method several times in attempts to clarify a possible role of 5-HT neurotransmission in the mechanism of two side effects of (atypical) antipsychotic drugs: dyskinesia [41-44] and hyperprolactinemia [45]. Therefore, studying the contribution of 5-HT neurotransmission in the mechanisms of MetS can be considered a logical next step. However, due to the complex involvement of genuine metabolic as well as endocrine, immunological, and behavioral mechanisms [46-50], body weight is also considered in this study.

\section{Materials and Methods}

\subsection{Patients}

This study was conducted according to the protocol approved by the Bioethical Committee of the Mental Health Research Institute of the Tomsk National Research Medical Center of the Russian Academy of Sciences (Protocol 187, approval on 24.04.2018). After obtaining informed consent we recruited 475 patients with schizophrenia being treated at the clinics of the Research Institute of Mental Health of the Tomsk National Research Medical Center, the Tomsk Clinical Psychiatric Hospital, the Hospital of the Siberian State Medical University, the Kemerovo Regional Clinical Psychiatric Hospital, and the N.N. Solodnikova Clinical Psychiatric Hospital of Omsk in the Russian Federation.

The main criteria for the inclusion of patients in the study were a verified diagnosis of schizophrenia according to ICD-10 (International Classification of Diseases, 10th revision) criteria as assessed by applying a structured clinical interview (Structured Clinical Interview for the DSM [SCID]), age 18-65 years, the patient's informed consent, Caucasian appearance, and the absence of severe organic pathology or somatic disorders in the stage of decompensation.

The antipsychotic and concomitant therapy received at the time of the examination (drugs, dosages used, duration of current drug use) were assessed, as well as previous antipsychotic and concomitant somatic therapy during the preceding six months. We used the chlorpromazine equivalent (CPZeq) daily dosage to standardize the dose, efficacy, and side effects of antipsychotics [51].

MetS was diagnosed according to the criteria of the International Diabetes Federation (IDF, 2005) [52], including the definition of abdominal obesity (waist circumference more than $94 \mathrm{~cm}$ in men, or more than $80 \mathrm{~cm}$ in women) and the presence of any two of the following four signs:

1. Concentration of triglycerides (TG) above $1.7 \mathrm{mmol} / \mathrm{L}$, or lipid-lowering therapy;

2. Concentration of high-density lipoproteins (HDL) of less than $1.03 \mathrm{mmol} / \mathrm{L}$ in men, or less than $1.29 \mathrm{mmol} / \mathrm{L}$ in women;

3. Blood pressure (BP) greater than or equal to $130 / 85 \mathrm{~mm} \mathrm{Hg}$, or the usage of antihypertensive therapy;

4. Concentration of glucose in blood serum greater than or equal to $5.6 \mathrm{mmol} / \mathrm{L}$, or previously diagnosed type 2 diabetes mellitus.

\subsection{Genetic Analysis}

Blood samples for biochemical and pharmacogenetic studies were taken by antecubital venipuncture in vacutainer tubes with $\mathrm{SiO}_{2}$ as a clot activator (to obtain serum) or with EDTA (to isolate genomic DNA by the standard phenol-chloroform method).

Genotyping of nine single-nucleotide polymorphisms (SNPs) of genes of the serotonergic system HTR1A (rs1423691, rs878567), HTR2A (rs6314), HTR3A (rs2276302, rs1150226), HTR2C (rs1414334, rs521018, rs498177), and SLC6A4 (rs16965628) was carried out using a MassARRAY ${ }^{\circledR}$ Analyzer 4 mass spectrometer (Agena Bioscience ${ }^{\mathrm{TM}}$ ) and a QuantStudio ${ }^{\mathrm{TM}}$ 
3D Digital PCR System Life Technologies amplifier (Applied Biosystems) using TaqMan Validated SNP Genotyping Assay kits (Applied Biosystems) based at The Core Facility "Medical Genomics", Tomsk National Research Medical Center of the Russian Academy of Sciences.

\subsection{Statistical Analysis}

Statistical analysis was carried out using SPSS software, release 23.0. The HardyWeinberg equilibrium (HWE) of genotypic frequencies was tested by the chi-square test. Pearson's chi-squared test was used for between-group comparisons of genotypic and allelic frequencies at a significance level of $p<0.05$. Assessment of the association of genotypes and alleles of the studied polymorphic variants of genes with a pathological phenotype was carried out using the odds ratio (OR) with a 95\% confidence interval for the odds ratio $(95 \% \mathrm{CI})$.

\section{Results}

A total of 475 patients receiving long-term antipsychotic therapy were examined. Metabolic syndrome was diagnosed in 126 patients (26.5\%). Table 1 presents the main demographic and clinical parameters of the studied patient groups.

Table 1. Demographic and clinical parameters of the studied patient groups.

\begin{tabular}{|c|c|c|c|c|}
\hline & & $\begin{array}{l}\text { Patients without MetS, } \\
n=349(73.5 \%)\end{array}$ & $\begin{array}{l}\text { Patients with MetS, } \\
\quad n=126(26.5 \%)\end{array}$ & $p$-Value \\
\hline \multirow{2}{*}{ Gender } & Women & $142(40.7 \%)$ & $72(57.1 \%)$ & \multirow{2}{*}{0.001} \\
\hline & Men & $207(59.3 \%)$ & $54(42.9 \%)$ & \\
\hline \multicolumn{2}{|c|}{$\begin{array}{l}\text { Age, years } \\
M \pm S D\end{array}$} & $38.72 \pm 11.43$ & $43.75 \pm 11.72$ & $<0.0001$ \\
\hline \multicolumn{2}{|c|}{$\begin{array}{c}\text { duration of illness, years } \\
\text { Me [Q1; Q3]. }\end{array}$} & $12.0[6.0 ; 20.0]$ & $17.0[9.0 ; 22.0]$ & 0.001 \\
\hline \multicolumn{2}{|c|}{$\begin{array}{l}\text { CPZeq, dose } \\
\text { Me [Q1; Q3]. }\end{array}$} & $400.0[225.0 ; 750.0]$ & $400.0[203.0 ; 741.0]$ & 0.919 \\
\hline \multicolumn{2}{|c|}{$\begin{array}{l}\text { Body mass index (BMI) } \\
\qquad \mathrm{M} \pm \mathrm{SD}\end{array}$} & $24.45 \pm 4.83$ & $30.45 \pm 6.36$ & $<0.0001$ \\
\hline
\end{tabular}

Note. Me [Q1; Q3]—-median and quartiles (first and third); MetS: metabolic syndrome; CPZeq: chlorpromazine equivalent; $\mathrm{M} \pm \mathrm{SD} — \mathrm{mean}$ and standard deviation.

In our sample, MetS was more often diagnosed in women with schizophrenia. The patients with MetS were significantly older $(p<0.0001)$, and the duration of illness in these patients was significantly longer than that in patients without MetS $(p=0.001)$. The study groups also showed significant differences in body mass index $(p<0.0001)$.

Deviation from the HWE was found for the rs1150226 polymorphic variant of the HTR3A gene; hence, this polymorphism was excluded from further consideration. As the HTR2C gene is located on the $\mathrm{X}$ chromosome, its polymorphic variants should not meet HWE. Taking this localization into account, the distributions of the genotype and allele frequencies of the studied HTR2C genes (rs1414334, rs521018, and rs498177) were analyzed separately in the groups of women $(n=214)$ and men $(n=261)$.

There were no statistically significant differences in any of the eight studied SNPs of genes of the serotonergic system and metabolic syndrome in patients with schizophrenia receiving antipsychotic therapy for a long time. Statistically significant associations were, however, revealed in groups of patients with BMI of $<25$ and BMI of $>25$ (Table 2).

Statistically significant differences in the distribution of genotype frequencies were found for the polymorphic variant rs521018 of the HTR2C gene in the group of women with schizophrenia $(p=0.033)$. Carriage of the heterozygous genotype GT causes a predisposition to increased weight gain in women receiving antipsychotic treatment (OR 1.97; 95\% CI: 1.09-3.55). 
Table 2. Distributions of alleles and genotypes of HTR2C single-nucleotide polymorphism (SNPs) in groups of patients with body mass index (BMI) values of $<25$ and $>25$.

\begin{tabular}{|c|c|c|c|c|c|c|c|}
\hline SNP & $\begin{array}{c}\text { Genotypes, } \\
\text { Alleles }\end{array}$ & BMI $<25$ & BMI > 25 & OR & $95 \%$ CI & $x^{2}$ & $p$ Value \\
\hline \multirow{5}{*}{$\begin{array}{l}\text { HTR2C } \\
\text { rs521018 }\end{array}$} & GG & $12(13.8)$ & $5(5.2)$ & 0.34 & $0.12-1.02$ & \multirow{3}{*}{6.85} & \multirow{3}{*}{0.033} \\
\hline & GT & 38 (43.7) & $58(60.4)$ & 1.97 & $1.09-3.55$ & & \\
\hline & $\mathrm{TT}$ & $37(42.5)$ & $33(34.4)$ & 0.71 & $0.39-1.29$ & & \\
\hline & G & $62(35.6)$ & $68(35.4)$ & 0.99 & $0.65-1.52$ & \multirow{2}{*}{0.00} & \multirow{2}{*}{0.965} \\
\hline & $\mathrm{T}$ & $112(64.4)$ & $124(64.6)$ & 1.01 & $0.66-1.55$ & & \\
\hline
\end{tabular}

\section{Discussion}

The complexity of 5-HT signaling lies in the large number of receptor genes encoding for seven main 5-HT receptor types with several further subtypes, dimerization with other receptor proteins, and RNA editing and alternative splicing of receptor transcripts $[20,23,53,54]$. Several serotonin receptors are involved in the regulation of metabolic homeostasis, such as 5-HT1A, 5-HT2A, 5-HT2C, 5-HT3, and 5-HT6 [7,11,20]. Agonists of 5-HT1A and 5-HT2C have opposite effects on food intake: 5-HT1A receptors increase food intake, while $5-\mathrm{HT} 2 \mathrm{C}$ receptors decrease appetite $[55,56]$. The selective $5-\mathrm{HT} 2 \mathrm{C}$ agonist lorcaserin has been approved in the USA for supportive treatment in weight management [57]. Among all 5- $\mathrm{HT}$ receptors, the 5- $\mathrm{HT} 2 \mathrm{C}$ are most strongly involved in the pharmacological action of serotonin [54]. Particularly, 5-HT2C expressed by a subset of pro-opiomelanocortin neurons in the hypothalamic arcuate nucleus and the brainstem nucleus of the solitary tract have a crucial role in mediating anti-orexigenic activity $[56,58]$. In humans, antagonization of the $5-H T 2 C$ receptor by atypical antipsychotics such as clozapine and olanzapine leads to weight gain [59-61].

In our study, we failed to establish an association between eight HTR genotypes and MetS. This may be due to the limited number of patients with MetS, but it is more likely due to the complex involvement of serotonergic transmission as well as other neurotransmitters in the mechanisms of the separate components of MetS. When studying one of these (indirect) components, we could find a relationship between rs521018 of HTR2C and increased body weight.

Many allelic variants of the HTR2C gene have been studied in the context of weight gain induced by antipsychotic therapy. These include rs $6318^{*} \mathrm{G}, \mathrm{rs} 3813928^{*} \mathrm{~A}, \mathrm{rs} 1414334^{*} \mathrm{C}$, rs $498207^{*} \mathrm{~A}$, rs $518147^{*} \mathrm{C}, \mathrm{rs} 498177^{*} \mathrm{C}$, and rs521018* $\mathrm{T}$. A study by Mulder and colleagues showed that the rs $1414334^{*} \mathrm{C}$ allele is associated with MetS in patients taking clozapine (OR 9.20; 95\% CI 1.95-43.45) or risperidone (OR 5.35; 95\% CI 1.26-22.83) [62]. In a study by Bai et al., the polymorphic variant rs 498177 showed a significant association with MetS in female patients, and allele $C$ was associated with an increased risk of MetS $(p=0.0007)$ [63]. However, the haplotype of the polymorphic variants rs521018*A and $\mathrm{rs} 498177^{*} \mathrm{C}$ in the HTR2C gene significantly reduces the risk of MetS (adjusted $p=0.0108$ ) in women [63].

Unfortunately, rs1150226 of HTR3A did not meet the HWE criterion as the A allele was significantly associated with higher BMI (data not shown). Antipsychotic drugs can also interfere with the expression of various receptors and the release of neurotransmitters. Polymorphic variants of the HTR3A gene (rs2276302, rs1062613, and rs1150226) have been shown to be associated with the response to clozapine therapy [64], which may contribute to weight gain $[37,60]$. Antipsychotics such as clozapine and olanzapine cause significant metabolic overload but are considered effective treatments for patients who do not respond to other therapies. Therefore, rs1150226 should be studied again in an independent patient population.

Further study of the molecular genetic factors of MetS and the mechanisms by which antipsychotics affect metabolic parameters is necessary to assess the risk of metabolic disorders and the implementation and individual approach to therapeutic tactics. It is possibly useful to expand the studied sample and to include in the analysis other risk 
factors for the development of MetS, such as the antipsychotic therapy used, smoking, and lifestyle, as well as to study individual components of MetS in patients.

\section{Conclusions}

Our study did not show an association of serotonin receptor genes with MetS in patients with schizophrenia. However, associations of one of the studied polymorphic variants with an increased BMI were revealed. Metabolic syndrome is a complicated symptoms complex that consists of separate components, including obesity, dyslipidemia, impaired glucose metabolism, and arterial hypertension. Serotonin is involved in these pathophysiological processes to varying degrees. We suggest that the involvement of serotonergic neurotransmission in MetS should be better studied after dissecting the syndrome into its individual (causal) components.

Author Contributions: Conceptualization, A.S.B., E.G.K., A.J.M.L. and S.A.I.; methodology, A.S.B., E.G.K., A.J.M.L. and S.A.I.; software, A.V.B.; validation, D.Z.P., A.S.B. and O.Y.F.; formal analysis, D.Z.P.; investigation, D.Z.P., A.S.B., I.V.P., A.V.B. and I.A.M.; resources, N.A.B. and S.A.I.; data curation, A.S.B. and E.G.K.; writing—original draft preparation, D.Z.P. and A.J.M.L.; writing—review and editing, A.J.M.L., O.Y.F. and S.A.I.; visualization, D.Z.P. and A.J.M.L.; supervision, A.V.S., N.A.B., and S.A.I.; project administration, S.A.I.; funding acquisition, A.S.B. All authors have read and agreed to the published version of the manuscript.

Funding: This research was funded by the Russian Science Foundation (project no. 19-75-10012).

Institutional Review Board Statement: This study was conducted according to the guidelines of the Declaration of Helsinki and approved by the Ethics Committee of the Mental Health Research Institute of the Tomsk National Research Medical Center of the Russian Academy of Sciences (protocol 187 approved on 24 April 2018).

Informed Consent Statement: Informed consent was obtained from all subjects involved in the study.

Data Availability Statement: The datasets generated for this study will not be made publicly available, but they are available on reasonable request to Svetlana A. Ivanova (ivanovaniipz@gmail.com), following approval of the Board of Directors of the MHRI, in line with local guidelines and regulations.

Acknowledgments: The authors are grateful to the Tomsk Clinical Psychiatric Hospital (Sergey M. Andreev), the Kemerovo Regional Clinical Psychiatric Hospital (Veronika A. Sorokina), and the N.N. Solodnikova Clinical Psychiatric Hospital of Omsk (Andrey I. Cheperin) for their help in recruiting patients for this investigation.

Conflicts of Interest: The authors declare no conflict of interest. The funders had no role in the design of the study; in the collection, analyses, or interpretation of data; in the writing of the manuscript; or in the decision to publish the results.

\section{References}

1. De Hert, M.; Detraux, J.; van Winkel, R.; Yu, W.; Correll, C.U. Metabolic and cardiovascular adverse effects associated with antipsychotic drugs. Nat. Rev. Endocrinol. 2011, 8, 114-126. [CrossRef]

2. O'Neill, S.; O'Driscoll, L. Metabolic syndrome: A closer look at the growing epidemic and its associated pathologies. Obes. Rev. 2015, 16, 1-12. [CrossRef]

3. Rojo, L.E.; Gaspar, P.A.; Silva, H.; Risco, L.; Arena, P.; Cubillos-Robles, K.; Jara, B. Metabolic syndrome and obesity among users of second generation antipsychotics: A global challenge for modern psychopharmacology. Pharmacol. Res. 2015, 101, 74-85. [CrossRef]

4. Freyberg, Z.; Aslanoglou, D.; Shah, R.; Ballon, J.S. Intrinsic and Antipsychotic Drug-Induced Metabolic Dysfunction in Schizophrenia. Front. Neurosci. 2017, 11, 432. [CrossRef]

5. Ijaz, S.; Bolea, B.; Davies, S.; Savović, J.; Richards, A.; Sullivan, S.; Moran, P. Antipsychotic polypharmacy and metabolic syndrome in schizophrenia: A review of systematic reviews. BMC Psychiatry 2018, 18, 275. [CrossRef] [PubMed]

6. Penninx, B.W.J.H.; Lange, S.M.M. Metabolic syndrome in psychiatric patients: Overview, mechanisms, and implications. Dialogues Clin. Neurosci. 2018, 20, 63-73. [CrossRef] [PubMed]

7. Panariello, F.; De Luca, V.; de Bartolomeis, A. Weight gain, schizophrenia and antipsychotics: New findings from animal model and pharmacogenomic studies. Schizophr. Res. Treatment 2011, 2011, 459284. [CrossRef] 
8. Stępnicki, P.; Kondej, M.; Kaczor, A.A. Current Concepts and Treatments of Schizophrenia. Molecules 2018, 23, 2087. [CrossRef] [PubMed]

9. Aringhieri, S.; Carli, M.; Kolachalam, S.; Verdesca, V.; Cini, E.; Rossi, M.; McCormick, P.J.; Corsini, G.U.; Maggio, R.; Scarselli, M. Molecular targets of atypical antipsychotics: From mechanism of action to clinical differences. Pharmacol. Ther. 2018, $192,20-41$. [CrossRef] [PubMed]

10. Ballon, J.S.; Pajvani, U.; Freyberg, Z.; Leibel, R.L.; Lieberman, J.A. Molecular pathophysiology of metabolic effects of antipsychotic medications. Trends Endocrinol. Metab. 2014, 25, 593-600. [CrossRef] [PubMed]

11. Namkung, J.; Kim, H.; Park, S. Peripheral Serotonin: A New Player in Systemic Energy Homeostasis. Mol. Cells 2015, 38, 1023-1028. [CrossRef]

12. Selvaraj, S.; Arnone, D.; Cappai, A.; Howes, O. Alterations in the serotonin system in schizophrenia: A systematic review and meta-analysis of postmortem and molecular imaging studies. Neurosci. Biobehav. Rev. 2014, 45, 233-245. [CrossRef] [PubMed]

13. Loonen, A.J.M.; Ivanova, S.A. Circuits regulating pleasure and happiness: Evolution and role in mental disorders. Acta Neuropsychiatr. 2018, 30, 29-42. [CrossRef] [PubMed]

14. Loonen, A.J.M.; Ivanova, S.A. The evolutionary old forebrain as site of action to develop new psychotropic drugs. J. Psychopharmacol. 2018, 32, 1277-1285. [CrossRef] [PubMed]

15. Loonen, A.J.M.; Ivanova, S.A. Evolution of circuits regulating pleasure and happiness with the habenula in control. CNS Spectr. 2019, 24, 233-238. [CrossRef] [PubMed]

16. Loonen, A.J.M.; Ivanova, S.A. Circuits regulating pleasure and happiness in major depression. Med. Hypotheses 2016, 87, 14-21. [CrossRef]

17. Loonen, A.J.M.; Ivanova, S.A. Circuits Regulating Pleasure and Happiness-Mechanisms of Depression. Front. Hum. Neurosci. 2016, 10, 571. [CrossRef]

18. Loonen, A.J.M.; Ivanova, S.A. Role of 5-HT2C receptors in dyskinesia. Int. J. Pharm. Pharm. Sci. 2016, 8, 5-10. Available online: https://innovareacademics.in/journals/index.php/ijpps/article/view/8736 (accessed on 4 March 2021).

19. Voigt, J.P.; Fink, H. Serotonin controlling feeding and satiety. Behav. Brain Res. 2015, 277, 14-31. [CrossRef]

20. Wyler, S.C.; Lord, C.C.; Lee, S.; Elmquist, J.K.; Liu, C. Serotonergic Control of Metabolic Homeostasis. Front. Cell Neurosci. 2017, 11, 277. [CrossRef]

21. Reynolds, G.P. Receptor mechanisms in the treatment of schizophrenia. J. Psychopharmacol. 2004, 18, 340-345. [CrossRef]

22. Meltzer, H.Y. Serotonergic mechanisms as targets for existing and novel antipsychotics. Handb. Exp. Pharmacol. 2012, 212, 87-124. [CrossRef]

23. Hannon, J.; Hoyer, D. Molecular biology of 5-HT receptors. Behav. Brain Res. 2008, 195, 198-213. [CrossRef]

24. Leysen, J.E. 5-HT2 receptors. Curr. Drug Targets CNS Neurol. Disord. 2004, 3, 11-26. [CrossRef]

25. Lychkova, A.É. Serotoninergic regulation of colonic motor function. Ter. Arkh. 2013, 85, 89-92. Available online: https: / / ter-arkhiv.ru/0040-3660/article/view/31237 (accessed on 4 March 2021).

26. Matsumoto-Miyai, K.; Yoshizumi, M.; Kawatani, M. Regulatory Effects of 5-Hydroxytryptamine Receptors on Voiding Function. Adv. Ther. 2015, 32 (Suppl. S1), 3-15. [CrossRef] [PubMed]

27. Padhariya, K.; Bhandare, R.; Canney, D.; Velingkar, V. Cardiovascular Concern of 5-HT2B Receptor and Recent Vistas in the Development of Its Antagonists. Cardiovasc. Hematol. Disord. Drug Targets 2017, 17, 86-104. [CrossRef] [PubMed]

28. Aloyo, V.J.; Berg, K.A.; Spampinato, U.; Clarke, W.P.; Harvey, J.A. Current status of inverse agonism at serotonin2A (5-HT2A) and 5-HT2C receptors. Pharmacol. Ther. 2009, 121, 160-173. [CrossRef] [PubMed]

29. Karunakaran, S.; Clee, S.M. Genetics of metabolic syndrome: Potential clues from wild-derived inbred mouse strains. Physiol. Genom. 2018, 50, 35-51. [CrossRef]

30. Stančáková, A.; Laakso, M. Genetics of metabolic syndrome. Rev. Endocr. Metab. Disord. 2014, 15, 243-252. [CrossRef] [PubMed]

31. Kroeze, W.K.; Hufeisen, S.J.; Popadak, B.A.; Renock, S.M.; Steinberg, S.; Ernsberger, P.; Jayathilake, K.; Meltzer, H.Y.; Roth, B.L. H1histamine receptor affinity predicts short-term weight gain for typical and atypical antipsychotic drugs. Neuropsychopharmacology 2003, 28, 519-526. [CrossRef]

32. Li, P.; Tiwari, H.K.; Lin, W.Y.; Allison, D.B.; Chung, W.K.; Leibel, R.L.; Yi, N.; Liu, N. Genetic association analysis of 30 genes related to obesity in a European American population. Int. J. Obes. 2014, 38, 724-729. [CrossRef]

33. Halder, I.; Muldoon, M.F.; Ferrell, R.E.; Manuck, S.B. Serotonin Receptor 2A (HTR2A) Gene Polymorphisms Are Associated with Blood Pressure, Central Adiposity, and the Metabolic Syndrome. Metab. Syndr. Relat. Disord. 2007, 5, 323-330. [CrossRef] [PubMed]

34. Chen, C.; Chen, W.; Chen, C.; Moyzis, R.; He, Q.; Lei, X.; Li, J.; Wang, Y.; Liu, B.; Xiu, D.; et al. Genetic variations in the serotoninergic system contribute to body-mass index in Chinese adolescents. PLoS ONE 2013, 8, e58717. [CrossRef]

35. Opgen-Rhein, C.; Brandl, E.J.; Müller, D.J.; Neuhaus, A.H.; Tiwari, A.K.; Sander, T.; Dettling, M. Association of HTR2C, but not LEP or INSIG2, genes with antipsychotic-induced weight gain in a German sample. Pharmacogenomics 2010, 11, 773-780. [CrossRef] [PubMed]

36. Reynolds, G.P.; Zhang, Z.J.; Zhang, X.B. Association of antipsychotic drug-induced weight gain with a 5-HT2C receptor gene polymorphism. Lancet 2002, 359, 2086-2087. [CrossRef]

37. Reynolds, G.P.; Zhang, Z.; Zhang, X. Polymorphism of the promoter region of the serotonin 5-HT(2C) receptor gene and clozapine-induced weight gain. Am. J. Psychiatry 2003, 160, 677-679. [CrossRef] [PubMed] 
38. Yuan, X.; Yamada, K.; Ishiyama-Shigemoto, S.; Koyama, W.; Nonaka, K. Identification of polymorphic loci in the promoter region of the serotonin 5-HT2C receptor gene and their association with obesity and type II diabetes. Diabetologia 2000, 43, 373-376. [CrossRef] [PubMed]

39. Zai, C.C.; Tiwari, A.K.; Chowdhury, N.I.; Brandl, E.J.; Shaikh, S.A.; Freeman, N.; Lieberman, J.A.; Meltzer, H.Y.; Kennedy, J.L.; Müller, D.J. Association Study of Serotonin 3 Receptor Subunit Gene Variants in Antipsychotic-Induced Weight Gain. Neuropsychobiology 2016, 74, 169-175. [CrossRef]

40. Loonen, A.J.M.; Wilffert, B.; Ivanova, S.A. Putative role of pharmacogenetics to elucidate the mechanism of tardive dyskinesia in schizophrenia. Pharmacogenomics 2019, 20, 1199-1223. [CrossRef] [PubMed]

41. Al Hadithy, A.F.Y.; Ivanova, S.A.; Pechlivanoglou, P.; Semke, A.; Fedorenko, O.; Kornetova, E.; Ryadovaya, L.; Brouwers, J.R.B.J.; Wilffert, B.; Bruggeman, R.; et al. Tardive dyskinesia and DRD3, HTR2A and HTR2C gene polymorphisms in Russian psychiatric inpatients from Siberia. Prog. Neuropsycho. Pharmacol. Biol. Psychiatry 2009, 33, 475-481. [CrossRef] [PubMed]

42. Ivanova, S.A.; Loonen, A.J.M.; Pechlivanoglou, P.; Freidin, M.B.; Al Hadithy, A.F.Y.; Rudikov, E.V.; Zhukova, I.A.; Govorin, N.V.; Sorokina, V.A.; Fedorenko, O.Y.; et al. NMDA receptor genotypes associated with the vulnerability to develop dyskinesia. Transl. Psychiatry 2012, 2, e67. [CrossRef] [PubMed]

43. Ivanova, S.A.; Loonen, A.J.M.; Bakker, P.R.; Freidin, M.B.; Ter Woerds, N.J.; Al Hadithy, A.F.Y.; Semke, A.V.; Fedorenko, O.Y.; Brouwers, J.R.B.J.; Bokhan, N.A.; et al. Likelihood of mechanistic roles for dopaminergic, serotonergic and glutamatergic receptors in tardive dyskinesia: A comparison of genetic variants in two independent patient populations. SAGE Open Med. 2016, 4, 2050312116643673. [CrossRef] [PubMed]

44. Pozhidaev, I.V.; Paderina, D.Z.; Fedorenko, O.Y.; Kornetova, E.G.; Semke, A.V.; Loonen, A.J.M.; Bokhan, N.A.; Wilffert, B.; Ivanova, S.A. 5-Hydroxytryptamine Receptors and Tardive Dyskinesia in Schizophrenia. Front. Mol. Neurosci. 2020, 13, 63. [CrossRef] [PubMed]

45. Ivanova, S.A.; Osmanova, D.Z.; Freidin, M.B.; Fedorenko, O.Y.; Boiko, A.S.; Pozhidaev, I.V.; Semke, A.V.; Bokhan, N.A.; Agarkov, A.A.; Wilffert, B.; et al. Identification of 5-hydroxytryptamine receptor gene polymorphisms modulating hyperprolactinaemia in antipsychotic drug-treated patients with schizophrenia. World J. Biol. Psychiatry 2017, 18, 239-246. [CrossRef] [PubMed]

46. Boiko, A.S.; Mednova, I.A.; Kornetova, E.G.; Semke, A.V.; Bokhan, N.A.; Loonen, A.J.M.; Ivanova, S.A. Apolipoprotein serum levels related to metabolic syndrome in patients with schizophrenia. Heliyon 2019, 5, e02033. [CrossRef]

47. Boiko, A.S.; Mednova, I.A.; Kornetova, E.G.; Bokhan, N.A.; Semke, A.V.; Loonen, A.J.M.; Ivanova, S.A. Cortisol and DHEAS Related to Metabolic Syndrome in Patients with Schizophrenia. Neuropsychiatr. Dis. Treat. 2020, 16, 1051-1058. [CrossRef]

48. Kornetova, E.G.; Kornetov, A.N.; Mednova, I.A.; Dubrovskaya, V.V.; Boiko, A.S.; Bokhan, N.A.; Loonen, A.J.M.; Ivanova, S.A. Changes in Body Fat and Related Biochemical Parameters Associated With Atypical Antipsychotic Drug Treatment in Schizophrenia Patients With or Without Metabolic Syndrome. Front. Psychiatry 2019, 10, 803. [CrossRef]

49. Kornetova, E.G.; Kornetov, A.N.; Mednova, I.A.; Lobacheva, O.A.; Gerasimova, V.I.; Dubrovskaya, V.V.; Tolmachev, I.V.; Semke, A.V.; Loonen, A.J.M.; Bokhan, N.A.; et al. Body Fat Parameters, Glucose and Lipid Profiles, and Thyroid Hormone Levels in Schizophrenia Patients with or without Metabolic Syndrome. Diagnostics 2020, 10, 683. [CrossRef]

50. Mednova, I.A.; Boiko, A.S.; Kornetova, E.G.; Parshukova, D.A.; Semke, A.V.; Bokhan, N.A.; Loonen, A.J.M.; Ivanova, S.A. Adipocytokines and Metabolic Syndrome in Patients with Schizophrenia. Metabolites 2020, 10, 410. [CrossRef]

51. Andreasen, N.C.; Pressler, M.; Nopoulos, P.; Miller, D.; Ho, B.C. Antipsychotic dose equivalents and dose-years: A standardized method for comparing exposure to different drugs. Biol. Psychiatry 2010, 67, 255-262. [CrossRef] [PubMed]

52. Alberti, K.G.; Zimmet, P.; Shaw, J. Metabolic syndrome-a new world-wide definition. A Consensus Statement from the International Diabetes Federation. Diabet. Med. 2006, 23, 469-480. [CrossRef]

53. Łukasiewicz, S.; Polit, A.; Kędracka-Krok, S.; Wędzony, K.; Maćkowiak, M.; Dziedzicka-Wasylewska, M. Hetero-dimerization of serotonin 5-HT(2A) and dopamine D(2) receptors. Biochim. Biophys. Acta 2010, 1803, 1347-1358. [CrossRef] [PubMed]

54. Palacios, J.M.; Pazos, A.; Hoyer, D. A short history of the 5-HT2C receptor: From the choroid plexus to depression, obesity and addiction treatment. Psychopharmacology 2017, 234, 1395-1418. [CrossRef] [PubMed]

55. Dourish, C.T.; Hutson, P.H.; Curzon, G. Characteristics of feeding induced by the serotonin agonist 8-hydroxy-2-(di-npropylamino) tetralin (8-OH-DPAT). Brain Res. Bull. 1985, 15, 377-384. [CrossRef]

56. Xu, Y.; Jones, J.E.; Kohno, D.; Williams, K.W.; Lee, C.E.; Choi, M.J.; Anderson, J.G.; Heisler, L.K.; Zigman, J.M.; Lowell, B.B.; et al. 5-HT2CRs expressed by pro-opiomelanocortin neurons regulate energy homeostasis. Neuron 2008, 60, 582-589. [CrossRef]

57. Higgins, G.A.; Fletcher, P.J.; Shanahan, W.R. Lorcaserin: A review of its preclinical and clinical pharmacology and therapeutic potential. Pharmacol. Ther. 2020, 205, 107417. [CrossRef]

58. D'Agostino, G.; Lyons, D.; Cristiano, C.; Lettieri, M.; Olarte-Sanchez, C.; Burke, L.K.; Greenwald-Yarnell, M.; Cansell, C.; Doslikova, B.; Georgescu, T.; et al. Nucleus of the Solitary Tract Serotonin 5-HT2C Receptors Modulate Food Intake. Cell Metab. 2018, 28, 619-630. [CrossRef]

59. Malhotra, N.; Grover, S.; Chakrabarti, S.; Kulhara, P. Metabolic syndrome in schizophrenia. Indian J. Psychol. Med. 2013, 35, 227-240. [CrossRef]

60. Papanastasiou, E. The prevalence and mechanisms of metabolic syndrome in schizophrenia: A review. Ther. Adv. Psychopharmacol. 2013, 3, 33-51. [CrossRef] [PubMed] 
61. Pillinger, T.; McCutcheon, R.A.; Vano, L.; Mizuno, Y.; Arumuham, A.; Hindley, G.; Beck, K.; Natesan, S.; Efthimiou, O.; Cipriani, A.; et al. Comparative effects of 18 antipsychotics on metabolic function in patients with schizophrenia, predictors of metabolic dysregulation, and association with psychopathology: A systematic review and network meta-analysis. Lancet Psychiatry 2020, 7 , 64-77. [CrossRef]

62. Mulder, H.; Cohen, D.; Scheffer, H.; Gispen-de Wied, C.; Arends, J.; Wilmink, F.W.; Franke, B.; Egberts, A.C. HTR2C gene polymorphisms and the metabolic syndrome in patients with schizophrenia: A replication study. J. Clin. Psychopharmacol. 2009, 29, 16-20. [CrossRef]

63. Bai, Y.M.; Chen, T.T.; Liou, Y.J.; Hong, C.J.; Tsai, S.J. Association between HTR2C polymorphisms and metabolic syndrome in patients with schizophrenia treated with atypical antipsychotics. Schizophr. Res. 2011, 125, 179-186. [CrossRef] [PubMed]

64. Souza, R.P.; de Luca, V.; Meltzer, H.Y.; Lieberman, J.A.; Kennedy, J.L. Influence of serotonin 3A and 3B receptor genes on clozapine treatment response in schizophrenia. Pharm. Genom. 2010, 20, 274-276. [CrossRef] [PubMed] 